\title{
21. RUDISTS FROM DSDP LEG 43, SITE 384
}

\author{
Bob F. Perkins, The University of Texas at Arlington, Arlington, Texas
}

\section{INTRODUCTION}

Sixteen specimens of rudists (Mollusca, Bivalvia, Hippuritacea) recovered from DSDP Leg 43, Site 384, Cores 16 and 20 were examined. Rudists are restricted to the uppermost Jurassic and the Cretaceous and are typically associated with reef, bank, biostrome, or other deposits of shallow-water origin. The Site 384 rudists indicate an Albian (Cretaceous) date and suggest a shallow water origin for the intervals in which they occur.

\section{CORE 16}

\section{Description and Identification of Material}

Fourteen steinkerns or steinkern fragments of monopleurid (Monopleuridae) rudists from Core 16 in the $120-130 \mathrm{~cm}$ interval were examined. No evidence of original shell wall or of shell wall structures is preserved in any of these specimens. Most of the fragments are straight segments of steinkerns of attached valves. The fragments range from $2 \mathrm{~mm}$ in diameter by $6 \mathrm{~mm}$ in length up to $6 \mathrm{~mm}$ in diameter by $12 \mathrm{~mm}$ in length. Steinkerns of two complete specimens in which both the attached valve and free valve are preserved were recovered. One of these complete specimens is 6 $\mathrm{mm}$ in diameter by $16 \mathrm{~mm}$ in length and the other is 7 $\mathrm{mm}$ in diameter by $9 \mathrm{~mm}$ in length.

A $2 \times 6 \mathrm{~mm}$ fragment from Core 16 in the $85-90$ $\mathrm{cm}$ interval may be a rudist steinkern, but is too incomplete for positive identification.

Identification to ranks lower than Family Monopleuridae is not possible without preservation of dentition, shell wall structures, or external features.

\section{Age}

Although a specific identification is not possible from steinkerns alone, the size and general form of the complete (bivalved) specimens resembles the size and form of an undescribed species of Monopleuridae common in the lower Albian of central Texas and northern Mexico.

\section{Paleoecological Observàtions}

Monopleurid rudists typically built biostromes in protected shallow-water Cretaceous shelf areas between reefs, banks, or other barriers and the shoreline. Monopleurids were also very minor components of caprinid-coral reefs. The monopleurids in Core 16 are not associated with reef organisms, however, and probably reflect a very shallow restricted marine environment, although there is no evidence that the specimens are from a biostrome assemblage.

\section{CORE 20}

\section{Description and Identification of Material}

Two caprinid (Caprinidae) rudist fragments were recovered from Core 20 in the $105-108 \mathrm{~cm}$ interval. Both fragments are sufficiently well preserved to reveal the shell wall structures essential to the recognition of caprinid rudists. One fragment is a rounded segment about $13 \mathrm{~mm}$ in diameter exposing a section of a steinkern of the shell-mantle cavity and a small arc of the outer shell wall in which the pallial canals characteristic of caprinid rudists have been preserved as calcite linings, although the shell wall itself has been leached. The second fragment is a $21 \times 8 \times 15 \mathrm{~mm}$ section of the outer shell wall showing the characteristic caprinid pallial canals traversed by thin tabulae. The two fragments can be identified no more closely than Family Caprinidae and probably do not represent the same species. If they do represent the same species the fragments are from widely separated growth stages or from different valves.

\section{Age}

Both specimens display pyriform pallial canals typical of caprinid species that range from middle Aptian through the Albian. The spacing and form of the pallial canal tabulae in the second fragment, however, suggest that the material is probably not older than Albian.

\section{Paleoecological Observations}

In the Cretaceous of the Gulf and Caribbean region and of the Mediterranean area caprinid rudists are common components of reef assemblages, but they also occur in open-shelf organic banks and even in nearshore restricted bank assemblages. They are indicative of shallow-water environments probably no deeper than a few tens of feet. In the absence of other rudist types associated with barrier or shelf-edge reef assemblages, and in the absence of an associated abundant coral and/or stromatoporoid suite, the caprinids in Core 20 suggest a shallow-water shelf bank environment. 